\title{
Verzeichnis
}

\section{der Herren, welche für den achtzehnten Band Referate geliefert haben.}

(Die Verantwortlichkeit für den Inhalt der Referate tragen die Herren Referenten. Die in Klammern gesetzten Chiffern bezeichnen die Uebersetzer der in fremder Sprache eingesandten Referate.)

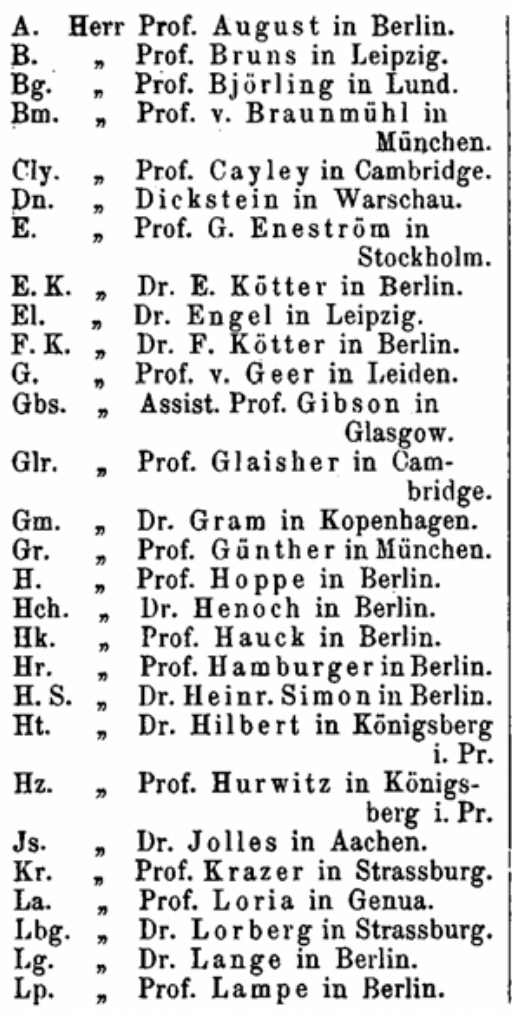

Ls. Herr Lazarus in Hamburg.

M. $\quad$ Prof. F. Müller in Berlin.

Mi. " Dr. Michaelis in Berlin.

M. L. " Prof. Mittag-Leffler in

Stockholm.

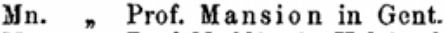

M-n. „ Prof. Mellin in Helsingfors.

My. \# Prof. F. Meyer in Clausthal.

Mz. ॠ Dr. Maynz in Ludwigslust.

N. $\quad$ Prof. Neumann in Leipzig.

No. " Prof. Netto in Giessen.

P. $\quad$ Ir. Petzold in Hannover.

Rdt. ” Dr. Reinhard t in Meissen.

R. M. , Dr. R. Müller in Berlin.

Rs. D Dr. Rosochatius in Berlin.

Sbt. " Dr. Siebert in Gross-

Lichterfelde.

Schg. \# Dr. Schlegel in Hagen.

Schn. " Prof. Schumann in Rerlin.

Scht. " Prof. Schubert in Hamburg.

Sn. " Dr. P. Simon in Berlin.

Std. " Prof. Studnička in Prag.

T. $\quad$ Dr. Toeplitz in Breslau.

Tn. " Prof. Treutlein in

Tx. ऋ Prof. Teixeira in Porto.

Vi., Dr. Vivanti in Mantua.

Wi. " Prof. A. Wassilieff in

Wn. . Prof. Wangerin in Kazan.

W.St. Prof. W. Stahl in Aach Wz. $₫$ Dr. Weltzien in Berlin.

Briefe und Zusendungen erbitten wir entweder durch Vermittelung der Verlagshandlung oder unter der Adresse:

Dr. Max Henoch, Berlin W, Vietoriastr. 29. 